\title{
PROBLEM SOLVING DALAM BISNIS E-COMMERCE Studi di Kelurahan Gadingharjo, Sanden, Bantul, Yogyakarta
}

\author{
Cahya Purnama Asri ${ }^{1}$, Niken Pernata Sari ${ }^{2}$ \\ Prodi Kewirausahaan ${ }^{1}$ \\ Prodi Kewirausahaan ${ }^{2}$ \\ Universitas Widya Mataram \\ cahyapurnama.uwm@gmail.com $^{1}$
}

\begin{abstract}
The introduction of online business in Gadingharjo village, Sanden, Bantul is still having problems because many villagers in Gadingharjo do not have modern mobile phones, and are not familiar in on line bussiness such as selling in Shopee, Toko Pedia, Buka Lapak and OLX.

Through this Community Partnership Program (PKM), the Proposal team tries to offer a solution to these problems through "problem solving socialization activities in E-commerce business".

Participants ask more about how to do business online, problems that might occur when doing business online because it involves business with people far away, both how the transaction, send goods, transfer money, take the money and how to respond to problems that occur .

Based on the results of the analysis and evaluation, the participant in the end was very enthusiastic in doing business so that they could take advantage of the handsets they had so that they produced profits.

Keywords: online business, socialization, transaction and problem solving
\end{abstract}

\begin{abstract}
Abstrak
Pengenalan bisnis online di Kelurahan Gadingharjo, Sanden, Bantul masih mengalami kendala karena banyak warga desa di Kelurahan Gadingharjo tidak memiliki hand phone yang modern dan belum familiar dengan bisnis online seperti berjualan di shopee, toko pedia, buka lapak dan OLX.

Melalui program Kemitraan Mayarakat (PKM) ini, tim pengusul mencoba menawarkan solusi terhadap permasalahan tersebut melalui kegiatan "sosialisai problem solving dalam bisnis E-commerce".

Peserta lebih banyak menanyakan mengenai cara melakukan bisnis online, permasalahanpermasalahan yang mungkin terjadi ketika dalam melakukan bisnis online karena menyangkut bisnis dengan orang jauh, baik bagaimana cara transaksinya, kirim barangnya, transfer uangnya, mengambil uangnya dan bagaimana cara menanggapi masalah-masalah yang terjadi.

Berdasarkan hasil analisa dan evaluasi peserta pada akhirnya sangat antusias dalam melakukan usaha sehingga bisa memanfaatkan hand phone yang mereka miliki sehingga menghasilkan keuntungan.
\end{abstract}

Kata kunci : bisnis online, sosialisasi, transaksi dan problem solving. 


\section{PENDAHULUAN}

Pertumbuhan ekonomi Daerah Istimewa Yogyakarta (DIY) pada 2018 berkisar antara 5,2 persen hingga 5,6 dibanding dengan tahun sebelumnya yaitu pada 2017 yang tumbuh 5,26 persen. Dengan demikian, perekonomian DIY berada dalam tren positif lebih tinggi di atas perekonomian nasional yakni 5,26 persen. Sementara perekonomian pusat stabil di angka 5,07 persen seiring tumbuhnya konsumsi masyarakat yang belum sepenuhnya pulih.

Keberadaan sektor Usaha Mikro Kecil dan Menengah (UMKM) amat signifikan dalam memacu pertumbuhan ekonomi baik di level lokal maupun nasional. UKMK dapat menyerap tenaga kerja cukup besar dan berkembang serta bersaing dengan perusahaan yang memiliki modal besar (capital intensive). Peran dari UMKM terbukti mampu memberikan sumbangan kepada pemerintah dan menjadi roda penggerak ekonomi, terutama pasca krisis ekonomi.

Di sisi lain, UMKM juga menghadapi banyak permasalahan, yaitu terbatasnya modal kerja, sumber daya manusia yang rendah dan minimnya penguasaan ilmu pengetahuan serta teknologi (Sudaryanto dan Hanim, 2002). UMKM begitu dekat dengan rakyat kecil, pertumbuhan ekonomi bergerak signifikan yang mana disebabkan oleh kemajuan UKM yang semakin berkembang (Kuncoro, 2008, Sripo, 2010).

Masalah utama yang sering dihadapi oleh UKM terungkap dalam sejumlah penelitian, pada umumnya seputar pemasaran produk (Hafsah, 2004; Kuncoro, 2008; Kurniawan, 2009; Supardi, 2009). Mereka menggunakan pemasaran dengan metode konvensional yang memerlukan biaya tinggi, seperti membuka cabang baru, ikut pameran, pembuatan dan penyebaran brosur.
Berbeda jauh dengan pemasaran dengan new media melalui internet. Internet menjadikan sarana yang sangat efektif dan efisien dalam membuka pemasaran dengan model online bagi produk UKM. Internet dapat menurunkan biaya operasional periklanan, penyebaran informasi akan lebih cepat dan jangkauannya lebih luas dengan menggunakan media sosial (Supardi, 2009). Munculnya internet menjadi awal mula munculnya $e$ commerce. Internet sendiri memiliki pengertian yaitu merupakan suatu media yang menggunakan teknologi komputer serta jaringan untuk mengurangi permasalahnpermasalahan seperti ruang dan waktu sehingga kita dapat mengakses informasi tanpa terhalang oleh ruang dan waktu tersebut. Sedangkan Electronic Commerce (ecommerce) menggambarkan proses membeli, menjual, mentransfer atau bertukar produk, jasa atau informasi melalui jaringan komputer, termasuk internet. E-business memiliki pengertian yang lebih luas lagi. Selain membeli dan menjual barang/jasa, e-business juga mengacu pada pelayanan konsumen, kolaborasi dengan partner bisnis dan melakukan transaksi elektronik dalam sebuah perusahaan (Rainer dan Cegilski, 2011).

Stancombe Research \& Planning, Deloitte Access Economics ( 2015) mengungkapkan sederet benefit teknologi digital dapat diperoleh UKM:(1) Aksesibilitas terhadap pelanggan baru di Indonesia $(50,2 \%)$, (2) Adanya peningkatan penjualan dan pendapatan (35,5\%), (3) Aksesibilitas market baru di luar negri $(33,7 \%)$, (4) kemudahan transaksi bagi pelanggan maupun pemasok $(27,7 \%)$, dan (5) Biaya Periklanan dan pemasaran yang lebih murah $(11,2 \%)$.

Peneliti lain Jensen, et. Al (2018) menambahkan bahwa pengembangan program digital dapat berupa: (1) peer-to-peer contact, yang menginspirasi pengusaha muda untuk menerapkan digitalisasi pada bisnisnya, (2) knowledge transfer, harus dilakukan secara nyata dan dipicu oleh kebutuhan bisnis 
masing-masing, (3) training, agar dapat menerapkan teknologi untuk tujuan praktis (4) intervention, harus dirancang sebagai tahapan proses bisnis sesuai dengan kebutuhan.

Masalah sosial yang terjadi di masyarakat mencakup multi bidang, baik bidang ekonomi dan masalah sosial lainnya. Masih terdapat tantangan besar dalam meningkatkan pertumbuhan ekonomi untuk mengurangi angka kemiskinan dan pengangguran tenaga kerja, menciptakan daya saing dan mengembangkan potensi yang tersedia karena belum bertambahnya jiwa kewirausahaan.

Oleh karena itu peneliti mengambil rumusan masalah sebagai berikut:

1. Apakah keterlambatan pengiriman dari suplayer berpengaruh terhadap penjualan online?

2. Apakah barang tidak sesuai ekspektasi pembeli berpengaruh terhadap penjualan online ?

3. Apakah masalah kerusakan pengiriman berpengaruh terhadap penjualan online?

4. Apakah penipuan/barang tidak dikirim berpengaruh terhadap penjualan online?

Tujuan pengabdian ini antara lain: untuk memberikan penjelasan mengenai keahlian komputer yang minim berpengaruh terhadap penjualan online; masalah kepercayaan diri yang berpengaruh terhadap penjualan online; kerusakan pengiriman yang berpengaruh terhadap penjualan online serta pembayaran berpengaruh terhadap penjualan online.

\section{METODE PENGABDIAN}

PELAKSANAAN

Pengabdian masyarakat ini secara khusus menyasar masyarakat yang ingin menjalankan usaha dan yang sudah menjalankan unit usaha dengan mempertimbangkan, peluang usaha yang dapat dikembangkan di Kelurahan Gadingharjo, Sanden, Bantul, Yogyakarta. Kelompok sasaran yang dicapai adalah :

1. Masyarakat umum yang memiliki keinginan untuk berwirausaha.

2. Perorangan atau kelompok pelaku UMKM tingkat pemula maupun sedang berjalan.

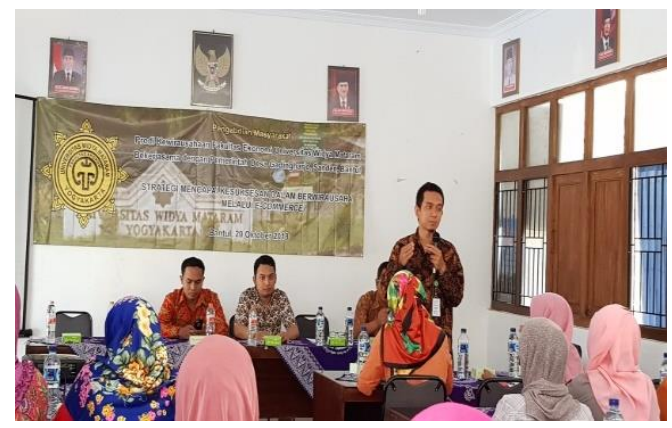

Gambar 1. Pengarahan Pengertian Problem Solving

Metode yang dilakukan dalam pengabdian kepada masyarakat adalah dengan memberikan pelatihan yang meliputi materi Problem Solving dalam Bisnis E-Commerce, sehingga sasaran dapat memperoleh pemahaman tentang bagaimana cara memecahkan masalah dalam bisnis online, sehingga dapat di kembangkan untuk menjalankan usaha sesuai dengan keterampilannya.

Metode Pelatihan

a. Pemaparan materi (class training) dengan cara memberikan ceramah dan model interaktif menjelaskan materi dipadukan dengan memberikan ilustrasi tentang bisnis online khusunya dalam problem solving bisnis online.

b. Memberikan kesempatan kepada peserta pelatihan untuk mengajukan pernyataan 
terkait dengan permasalahan yang dihadapi dalam melakukan bisnis online.

\section{HASIL DAN PEMBAHASAN}

\subsection{Pemecahan Masalah}

Pemecahan masalah merupakan suatu prosedur yang di dalamnya terdapat langkah-langkah yang harus diikuti dalam memecahkan masalah yang dihadapi seseorang sebagai perorangan atau seseorang sebagai pemimpin organisasi atau keanggotaan organisasi.

- Masalah dapat digambarkan sebagai suatu keadaan (terlihat atau tidak terlihat) dimana antara yang diharapkan dengan kenyataan tidak sesuai atau terdapat hambatan antara yang diinginkan dengan keadaan yang sebenarnya.

- Keluhan biasanya akibat dari masalah yang tidak jelas atau tidak teratasi/ tidak terselesaikan.

- Keluhan yang dirasakan seseorang dapat dijadikan pertanda seseorang sedang mengalami masalah yang tidak dikenali atau sebuah masalalah yang tidak terpecahkan.

Tahapan-tahapannya:

1. Bagaimana Menyikapi Masalah

Pada umumnya masalah yang dialami seseorang bersumber dari dirinya sendiri (internal) dan juga bersumber dari luar (external) dengan cara melakukan :
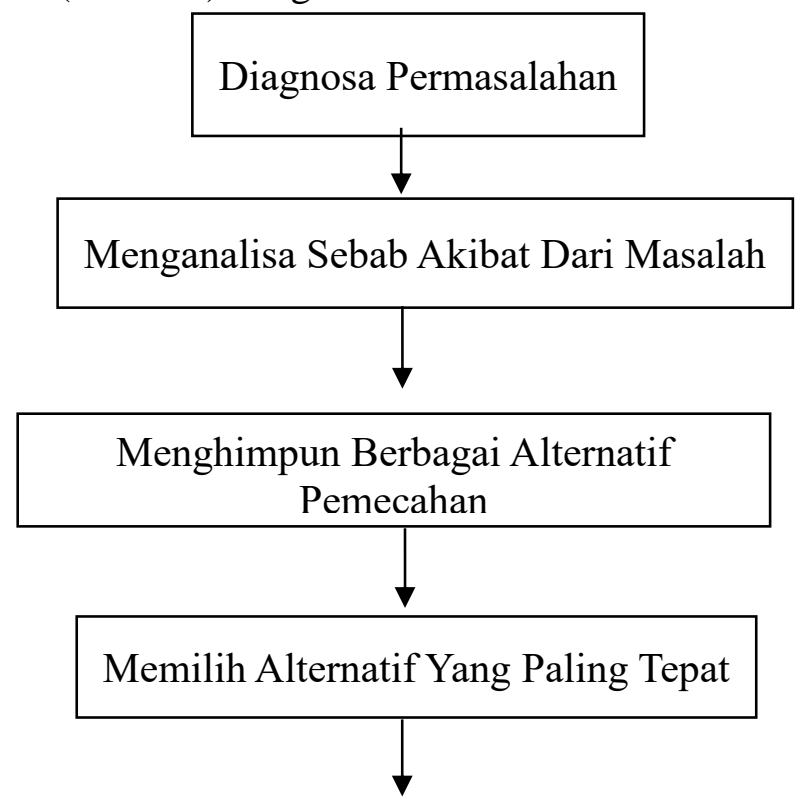

Melaksanakan Pilihan Dalam Bentuk Kegiatan Terencana

2 .Menganalisa Sebab Akibat dari Masalah Dalam suatu masalah memerlukan pengetahuan dan pengalaman, memerlukan data dan fakta yang jelas/akurat. Apabila data itu tidak ada maka masalah yang dihadapi akan sulit untuk mencari solusinya. Beberapa kesalahan umum yang sering muncul ketika kita menganalisa sebab dan akibat dari suatu permasalahan yaitu :

- Menyarankan pemecahan yang tidak relevan dengan masalahnya.

- Mendiskusikan apa yang seharusnya dikerjakan pada masa silam dan bukannya apa yang bisa dikerjakan saat ini.

- Membicarakan keuntungan dan kerugian suatu pemecahan sebelum setiap orang telah mendapat kesempatan untuk memberikan saran pemecahan.

- Memusatkan pada pemecahan-pemecahan yang telah digunakan pada masa sebelumnya tanpa suatu usaha menciptakan cara-cara pemecahan yang baru.

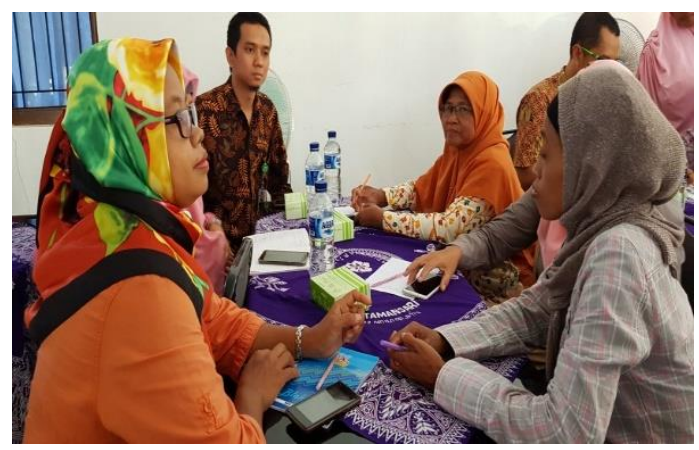

Gambar 2. Kegiatan diskusu secara berkelompok.

Secara keseluruhan kegiatan pengabdian kepada masyarakat terlaksana dengan baik dan lancar. Peserta sangat antusias mengikuti pelatihan dan berpartisipasi aktif dalam mengajukan pertanyaan atau 
mengungkapkan permasalahan yang dihadapi dalam usaha online.

Peserta lebih banyak menanyakan mengenai cara melakukan bisnis online, permasalahan-permasalahan yang mungkin terjadi ketika dalam melakukan bisnis online karena menyangkut bisnis dengan orang jauh, baik bagaimana cara transaksinya, kirim barangnya, transfer uangnya, mengambil uangnya dan bagaimana cara menanggapi masalahmasalah yang terjadi.

Pertanyaan dan permasalahan yang disampaikan peserta, dapat dijelasan pembicara, diikuti dengan praktik menggunakan aplikasi bisnis online yaitu shopee.

\section{KESIMPULAN}

Hasil kegiatan pengbadian menunjukkan beberapa hambatan dan solusi dalam bisnis online sebagai berikut:

a. Masalah keterlambatan pengiriman dari suplayer.

Solusi :Pembeli menyatakan estimasi waktu pengiriman serta kemungkinan keterlambatan pengiriman.

b. Masalah barang tidak sesuai ekspektasi pembeli.

Solusi : Foto promosi suatu produk, khususnya produk busana, lebih baik untuk menggunakan model sebagai foto promosi, karena lebih realistis dibandingkan foto promosi yang tidak menggunakan model.

c. Masalah kerusakan pengiriman.

Solusi : Jika seseorang ingin membeli suatu barang secara online, hendaknya ia mempelajari cara pengiriman barang tersebut yang aman menggunakan kurir tertentu yang lebih bagus dan bisa menjamin keutuhan barang tersebut dan menawarkan pada pembeli perlu tidak adanya asuransi barang.

d. Masalah penipuan/barang tidak dikirim.
Solusi : Mempelajari kinerja penjual online melalui respon-respon pelanggan yang biasanya tertera di halaman promosi penjual online. Ini juga dapat digunakan oleh penjual bisnis online, untuk menyediakan tempat bagi para pembeli untuk memberi respon yang dapat dibaca secara umum. Dengan respon-respon pembeli yang baik, berdampak pada meningkatnya reputasi penjual online hingga lebih terpercaya.

\section{Daftar Pustaka}

Deloitte Access Economics, 2015. UKM Pemicu Kemajuan Indonesia, Instrumen Pertumbuhan Nusantara.

Hafsah, M.J. 2004. Upaya Pengembangan Usaha Kecil dan Menengah (UKM). Jurnal Infokop Nomor 25 Tahun XX

Jensen, H. V., Tofalleti, S., Thornley, C., \& Murnane, S. 2018. Grand Coalition for Digital Jobs. Digital Skills for SMEs.

Kuncoro, Mudrajad, 2008. Tujuh Tantangan UKM di Tengah Krisis Global. Harian Bisnis Indonesia 21 Oktober 2008.

Rainer, R.K., \& Cegielski, C.G., 2011. Introduction to Information Systems : Supporting and Transforming Business ( $\left.3^{\text {rd }} \mathrm{ed}\right)$. United States : John Wiley \& Sons. 
Sripo, 2010. 38.044 UKM Serap 163.830 Tenaga Kerja. Harian Umum Sriwijaya Post Tanggal 15 April 2010 .

Sudaryanto, dan A. Hanim, 2002.

"Evaluasi kesiapan UKM

Menyongsong Pasar Bebas Asean (AFTA) : Analisis Perspektif dan Tinjauan Teoritis. ". Jurnal Ekonomi Akuntansi dan Manajemen, Vol. 1, No. 2.

Supardi, Julian, 2009. Rancang Bangun Collaborative System Pemasaran Hotel Secara online Dengan Pendekatan Mediator based. Jurnal Sistem Informasi Fasilkom Unsri Vol 1 No 2. 